December 2011

\title{
From Lemkin to Clooney: The Development and State of Genocide Studies
}

Dominik J. Schaller

Follow this and additional works at: https://digitalcommons.usf.edu/gsp

\section{Recommended Citation}

Schaller, Dominik J. (2011) "From Lemkin to Clooney: The Development and State of Genocide Studies," Genocide Studies and Prevention: An International Journal: Vol. 6: Iss. 3: Article 6.

Available at: https://digitalcommons.usf.edu/gsp/vol6/iss3/6

This Articles is brought to you for free and open access by the Open Access Journals at Digital Commons @ University of South Florida. It has been accepted for inclusion in Genocide Studies and Prevention: An International Journal by an authorized editor of Digital Commons @ University of South Florida. For more information, please contact digitalcommons@usf.edu. 


\title{
From Lemkin to Clooney: The Development and State of Genocide Studies
}

\author{
Dominik J. Schaller \\ Ruprecht-Karls-University, Heidelberg, Germany
}

The study of genocide has become one of the most attractive fields of research since the end of the Cold War. A productive and vibrant scholarly community has come into existence and professional associations compete with each other and foster international exchange by regularly organizing major conferences. Several scholarly journals contribute to a multifaceted research landscape. Similarly impressive is the progressive institutionalization of genocide studies. For most students and scholars, the study of genocide is more than just an academic or intellectual occupation. They see their roles as scholar-activists, but the will to stop genocide is not only prevalent in the ivory tower of academia. A whole plethora of actors in the realm of civil society are running stunning campaigns against genocide that attract both media and public attention. But is the evolution of genocide studies a single success story? This article highlights some methodological and ideological problems inherent in genocide studies (e.g., Eurocentrism) and discusses their consequences for our understanding of mass violence.

Key words: genocide studies, Eurocentrism, Lemkin, genocide prevention, Save Darfur movement

When Raphael Lemkin (1901-1959) coined the term "genocide" in 1944 he brought about a paradigmatic change in both international law and the social sciences. Already, in the interwar period, Lemkin had been struggling to establish international protection for minorities. The tragic fate of the Ottoman Armenians, in particular, had confirmed his opinion that an international law ought to be created to make the deliberate and systematic extermination of national or religious minorities by a state a punishable offense. However, Lemkin's proposals were rejected at the Fifth International Conference for the Unification of Penal Law in Madrid in 1933. It was only after the horrors of World War II that politicians and international lawyers recognized the importance of new paradigms. In April 1947, the secretary general of the newly founded United Nations commissioned Lemkin and two other leading specialists in international law to prepare a draft for a criminal code against genocide. The coming into effect of the UN Convention on the Prevention and Punishment of the Crime of Genocide (UNCG) would likely not have been possible without Lemkin's tireless commitment to lobbying for his convictions. The great innovation of the UNCG consisted of the juridical abolition of the principle of sovereignty. Before the adoption of the UNCG, states had been able, in principle, to persecute and annihilate parts of their population without being punished.

Lemkin left his mark not only on international law, but also on social and historical sciences. With his first definition of genocide, Lemkin revolutionized our understanding of mass violence:

Dominik J. Schaller, "From Lemkin to Clooney: The Development and State of Genocide Studies." Genocide Studies and Prevention 6, 3 (December 2011): 245-256. (C) 2011 Genocide Studies and Prevention. doi:10.3138/gsp.6.3.245 
By "genocide" we mean the destruction of a nation or of an ethnic group.... Generally speaking, genocide does not necessarily mean the immediate destruction of a nation, except when accomplished by mass killings of all members of a nation. It is intended rather to signify a coordinated plan of different actions aiming at the destruction of essential foundations of the life of national groups, with the aim of annihilating the groups themselves. ${ }^{1}$

Lemkin asserted that the destruction of national, ethnic, or religious groups was often carried out through non-lethal forms of violence. Consequently, genocide is more than a large-scale massacre. According to Lemkin, the perpetration of genocide has to be understood as a total social practice that affects all aspects of group life. ${ }^{2}$ As such, "genocide" is a useful analytical tool for the study of mass violence. After the adoption of the UNCG, Lemkin's interest in genocide became more and more social scientific. He dedicated a great deal of his creative power to the compilation of a global history of genocide. Cases of genocide, from ancient times to modernity, attracted his interest. Lemkin can thus be regarded as the father of genocide research. ${ }^{3}$

In many ways, the UNCG shared Lemkin's fate and became largely forgotten and, during the period of the Cold War, was an ineffectual statement of intent. Although the superpowers had the means to prevent and punish the crime of genocide, they preferred not to intervene in their allies' domestic affairs. Moreover, the accusation of genocide became an efficient instrument of propaganda. The opponents of the Cold War regularly accused one another of committing acts of genocide. Lemkin, for example, was an ardent anti-Communist and had close ties with Eastern European émigrés in the United States. He was convinced that the creation and cohesion of the Soviet Union were based on acts of mass violence against ethnic minorities and a policy of cultural genocide. ${ }^{4}$ As a result of this political exploitation, the term "genocide" degenerated into a rhetorical weapon, and the UNCG suffered from a lack of legitimation and credibility. The UNCG was further weakened by the absence of a monitoring and control system in effect. Tellingly, it was the end of the bipolar world order that led to significant changes regarding the significance of the UNCG. The appointment of the ad hoc tribunals for the wars of secession in the former Yugoslavia and the systematic murder of up to 800,000 Tutsi in Rwanda in 1994 as well as the adoption of the Rome Statute on the establishment of an International Criminal Court (ICC) in 1998 were impressive examples of a new international policy toward the punishment and prevention of mass violence. The deadlock of the Cold War period had finally been overcome.

Unsurprisingly, this development has had a profound impact on the academic study of genocide and other forms of mass violence. Whereas only an obscure circle of scholars dealt scientifically with genocide in the decades before 1989, genocide studies has become one of the most attractive fields of research in the past years. The literature on the subject is growing incessantly and, even for experts, it is difficult to keep an eye on all the different developments. Furthermore, Lemkin's early writings on genocide have been rediscovered, ${ }^{5}$ and he has finally gotten the recognition he deserves and is celebrated as the pioneer of genocide studies. "Genocide" has become an acknowledged term in the social sciences and is commonly used without reluctance. This can easily be proven with the aid of a tool developed by the Internet company Google. The Google labs Books Ngram Viewer allows us to examine the frequency of words or phrases over time. Over 5.2 million books scanned by Google (a total of 500 billion words) constitute the empirical foundation of this instrument. ${ }^{7}$ 


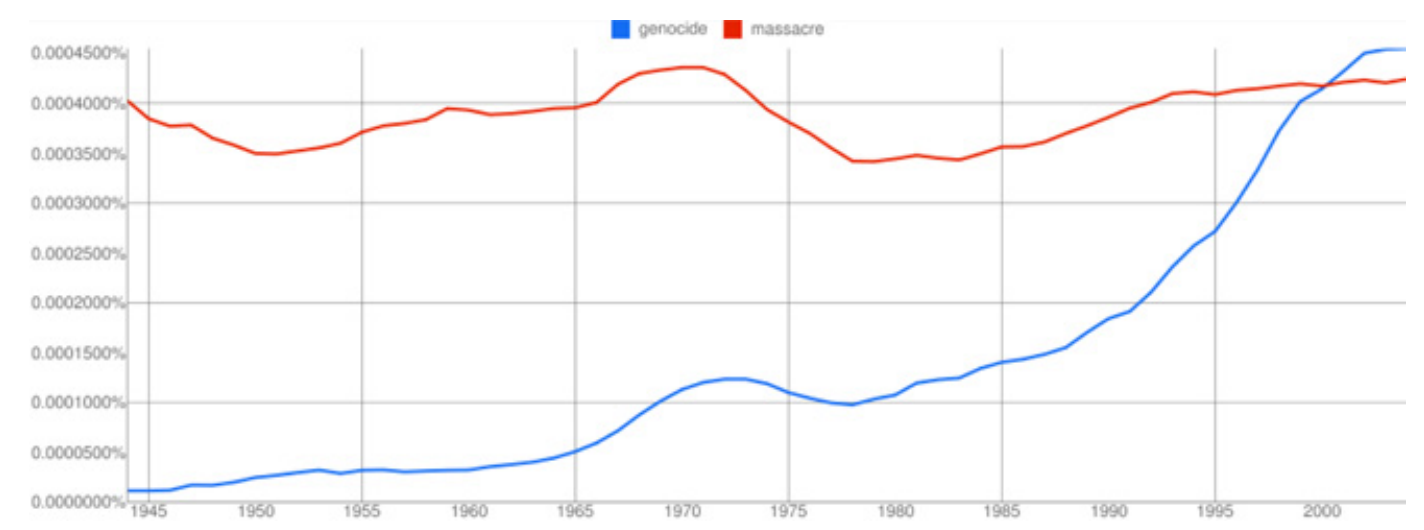

Figure 1. Frequency of the terms "genocide" and "massacre" from 1944 to $2004^{8}$

Figure 1 supports the assumption that the usage of the term "genocide" has rapidly increased since the end of the Cold War. Even more interesting is the fact that "genocide" has been used more often than the related term "massacre" since the late 1990s. This discovery suggests that "genocide" has become an expression synonymous with mass violence.

The triumph of the term "genocide" is reflected in the development of a productive and vibrant scholarly community. Two professional associations, the International Association of Genocide Scholars (IAGS) and the International Network of Genocide Scholars (INoGS), compete with each other and foster international scholarly exchange by regularly organizing major conferences. Several scholarly journals (e.g., Journal of Genocide Research (JGR); Genocide Studies and Prevention: An International Journal (GSP); Holocaust and Genocide Studies) contribute to a multifaceted research landscape. Similarly impressive is the progressive institutionalization of genocide studies. Research institutes can be found on all continents except Antarctica and, considering the enormous growth of this research field, it is only a matter of time until a genocide center will be founded on the perpetual ice. More and more universities offer attractive genocide studies programs that enjoy great popularity among students. For most students and scholars the study of genocide is more than just an academic or intellectual occupation. They see their roles as scholar-activists. It is largely accepted that only a better understanding of the causes, mechanisms, and dynamics of mass violence can contribute to an efficient and sustainable policy of genocide prevention. Therefore, a majority of scholars consider genocide studies to be an applied science. The will to stop genocide is not only prevalent in the ivory tower of academia. A whole plethora of actors in the realm of civil society are running stunning campaigns against genocide that attract both media and public attention. The Save Darfur campaign has been described as the largest international social movement since anti-apartheid. ${ }^{9}$ School children, students, politicians, and Hollywood celebrities like George Clooney are united in their wish to stop the ongoing genocide in the Western Sudanese province. It is considered good manners these days to support fund-raising campaigns for the innocent victims of Sudanese President Omar al-Bashir's cynical policy of extermination, organize protest marches, and circulate petitions that urge politicians to act. The Darfur movement reached its peak when activists under the leadership of film stars Mia Farrow and George Clooney called for a boycott of the "Genocide Olympics" in China in 2008 
because of Beijing's close economic ties with the regime in Khartoum. All these efforts have paid off as the media and the international public pay much more attention to the events and developments in Sudan.

The international community's reaction to the mass violence in Darfur differs significantly from the hesitant and ineffectual international response to the Rwandan Genocide in 1994. Representatives of the US government have declared the murder of the Fur, Masalit, and Zaghawa in Darfur to be genocide. Moreover, the UN Security Council referred the case to the ICC. As a consequence, the ICC issued an arrest warrant for the Sudanese president for the crime of genocide in Darfur. Omar alBashir is thus the first sitting head of state ever indicted by an international organization for genocide.

If one considers the developments I have just described and compares them to the difficult beginnings of the UNCG and the tragic fate of Raphael Lemkin, one has to come to the inevitable conclusion that the evolution of genocide studies is a pure success story. No one can deny that this is true in many respects. However, this narrative of constant and linear progress in genocide studies is delusive. It prevents scholars of mass violence from critically dealing with the results that have been achieved in the past years and from questioning traditional paradigms. Moreover, too much self-satisfaction allows us to ignore some shady trends in the realm of genocide studies. As welcome as the fact may be that Clooney and company support the fight against genocide, it is nonetheless regrettable to see that a veritable "genocide circus" has emerged. The sneaking suspicion that celebrities are publicly committed to preventing mass violence in order to raise their public relations value cannot be dismissed lightly. Genocide prevention has become a modern and highly efficient form of charity for the rich and the beautiful. Furthermore, it has become a lucrative business for dubious racketeers. The Save Darfur movement, for example, has been criticized for spending donated funds almost exclusively for public relations and lobby activities and not for needy Africans on the ground in Sudan. ${ }^{10}$

More than 10 years ago, Norman G. Finkelstein asked whether there is a "Holocaust industry" and launched a provocative, and in many ways problematic, discussion. ${ }^{11}$ This debate was spoiled by anti-Semitic arguments and conspiracy theories. When I speak about a "genocide industry" this does not mean I want to continue or reanimate the Finkelstein debate. However, the expression is appropriate since it cannot be denied that genocide sells. Book manuscripts related to mass violence need to carry "genocide" in their titles in order to be published and sold. "Genocide" and "prevention" are indispensable key terms that enhance the status of any research proposal. Another disturbing and morbid phenomenon is "genocide tourism." Genocide memorials and former killing fields are more and more commercialized and exploited for tourism. "Genocide" is even a sales argument for holidays in the "third world." The churches in Nyamata and Ntarama, where the skulls and bones of hundreds of victims are kept, are the main tourist attractions in Rwanda besides the mountain gorillas. ${ }^{12}$

How should researchers deal with these and other excesses related to the "genocide industry"? Without doubt, many scholars are tempted to benefit one way or another from the attraction and dark fascination of their subject. This is a rational reaction since scholars are dependent on public interest and good will. However, the reputation of genocide studies as such would sooner or later be irretrievably damaged if researchers did not manage to keep a critical distance from both activists and profitoriented actors in the field. The most important task is to elude instrumentalization in any form. The best way to achieve this goal is to constantly scrutinize the terms, 
concepts, categories, and methods that are commonly used in genocide studies. Although the study of mass violence has gained a high degree of seriousness, maturity, and scholarly respect in recent years, there are still some methodological and ideological problems that cast a cloud over the further development of genocide research. These problems will be discussed in depth below.

\section{Eurocentrism}

Although genocide research is conducted worldwide, the field is still dominated by Eurocentric attitudes and approaches. Genocide is commonly understood as a phenomenon that can only occur either in totalitarian regimes or in failing states in the so-called third world. According to this assumption, the best way to prevent mass violence would be the global spread of Western-style liberalism, capitalism, and democracy. The Australian historian A. Dirk Moses has subsumed these ideas under the term "liberal theory of genocide." 13 This concept is closely linked to modernization theory and to Francis Fukuyama's thesis of the end of history since the Western way of development is regarded as the only path that can lead to peace, prosperity, and international security or, in other words, to a world without genocide. As a consequence, adherents of the liberal theory of genocide see Western democracy as a kind of redeeming power that has to prevent or stop genocidal violence once it occurs in societies that lack democratic institutions and Western ideals of human rights. ${ }^{14}$ Of course, this does not mean that the West is perfect or without guilt. Western support of dubious dictatorial but anti-Communist regimes in Latin America and Africa during the period of the Cold War is now regarded as a moral mistake, and the ineffectual international reactions to the genocide in Rwanda and the wars in the former Yugoslavia are regarded as sins of omission. ${ }^{15}$ But the idea that Western democracies could themselves become perpetrators of mass violence contradicts the worldview of the liberal theory of genocide and is therefore rejected.

This is obvious when it comes to a discussion of the genocidal qualities of European colonialism. In traditional genocide studies, the history of European expansion and colonial rule is often depicted as a humanitarian triumphal procession. The colonial narrative of the mission civilisatrice is accepted without criticism, as the following quote from a general world history of genocide reveals: "the effect of the European presence was manifestly ameliorative, as were the long-term effects of the introduction of Western medicine, education and legal and customary practices, and the inclusion of these places in the modern global economic system." 16 In recent years, several historians have started to question the bias of the liberal theory of genocide studies and to examine the genocidal outcomes associated with the rise of the West. ${ }^{17}$ Although some scholars of mass violence still feel uneasy about the term "colonial genocide," many cases of imperial violence have been thoroughly researched recently. ${ }^{18}$ The best-known case is the murder of the Namibian Herero in former German Southwest Africa (1904-1908), which is portrayed in almost all recent books on the history of genocide and ethnic cleansing. It is of no surprise that there is huge interest in this particular incident of genocide. Although imperial Germany was a Western power, it was far from being a liberal democratic state. But what interests genocide scholars even more than the social and political structures of the German empire are alleged ideological and personal continuities from the systematic extermination of the Herero to the Nazi Holocaust less than 40 years later. ${ }^{19}$ These facts are consistent with the idea of the liberal theory of genocide studies that mass violence occurs mainly in dysfunctional and/or undemocratic states, which explains why the murder of the Herero is regarded as the ideal type of a colonial genocide. Colonial violence in Namibia 
is thus often understood as the result of the often-cited German Sonderweg (special path) and not as the logical result of colonial rule as such.

The neglect of colonial violence in genocide studies is astonishing if one considers how much importance Lemkin attached to colonialism. Lemkin dealt intensively with the genocidal consequences of European rule in the Americas and in Africa. Manuscripts on the Spanish genocides against the Aztecs and the Incas, the murder of the Herero, and the atrocities in the Belgian Congo can be found in his unpublished papers. ${ }^{20}$ Although Lemkin believed in the imperative for and advantages of the European civilizing mission, his original concept of genocide is a useful methodological tool for identifying the genocidal tendencies inherent in colonial rule. As I have already shown in the introductory part of this article, Lemkin's first definition of genocide does not exclusively describe the immediate extermination of a targeted group. Lemkin understood genocides as processes aimed at the destruction of a certain group's essential foundation of life and identified specific methods of group annihilation: political (cessation of self-government and destruction of political institutions), social (annihilation of national leadership, attack on legal system), cultural (ban on the use of language), economic (destruction of the foundation of economic existence), biological (decrease in the birth rate), physical (mass murder, endangering of health), religious (disruption of religious influence, destruction of religious leadership), and moral (creation of an atmosphere of moral debasement). ${ }^{21}$

These techniques of group destruction characterized European colonial rule in many parts of the world. Indigenes were normally not ready to abandon their subsistence economies and to work as cheap laborers on European owned plantations or mines. The indigenes' reluctance thus threatened the establishment of a "modern" European economic system in the colonies. To break indigenous resistance and unwillingness, Europeans embarked on the strategy of devastating the indigenous populations' economic independence. This objective was achieved through the deliberate destruction of indigenous cultures and traditional ways of life. The colonizers thus understood the forced settlement of nomadic groups and the persecution of huntergatherer societies as a necessary contribution to modernization. Christian missionaries were commissioned to inculcate European ethical values and a colonial working morale among their subject populations. European colonial officials and missionaries thus must be seen as agents of cultural genocide.

Great Britain and France were the leading imperial powers at the end of the nineteenth century. Despite their rhetoric of humanitarianism and progress, both states-liberal and democratic-committed several large-scale massacres as well as genocidal violence in their colonial realms. It is Eurocentric and therefore untenable to claim that only failing or totalitarian states are capable of resorting to genocide.

\section{Genocide: A Contested Concept}

Although Lemkin's initial use of "genocide," as laid out in Axis Rule in Occupied Europe, constituted the basis of a draft for a new international law, his colleagues at the UN took vastly different views regarding some crucial points. As outlined above, Lemkin considered the deliberate destruction of a group's culture to be a form of genocide. His colleagues, however, deemed this proposal to be an unacceptable extension of the term. Ultimately, as a result of international pressure, political groups and social classes were not accorded protection under the UNCG. What constitutes "genocide" was thus contested from the beginning.

Most genocide scholars try to remedy these shortcomings by redefining the term "genocide" or by creating new concepts. By now, a great variety of definitions of 
genocide and competing concepts exist: politicide, ethnocide, ecocide, gendercide, democide, autogenocide, genocidal massacre, and so on. As a consequence, "genocide" has degenerated into a collective name for mass murder. The popularity of the term confirms this (see Figure 1). The lack of a generally accepted definition as well as the vagueness of the term results in heated debates over which cases of mass murder should be classified as "genocide." I will come back to this point when discussing the impact of memory politics on genocide studies.

Further methodological problems stem from the origins of the concept of genocide. Transferring this concept from international law into the social and historical sciences has been rather difficult since lawyers and social scientists conceptualize and categorize differently. I wish to address the most eminent problems below. The definition of genocide by the UN identifies the express intention of perpetrators as a constitutive feature. ${ }^{22}$ In international law, only proof of this subjective component of the offense can result in a conviction on the count of genocide. Such an intentionalist view is problematic to reconcile with the findings of empirically oriented historical research. Studies on the Holocaust, the Armenian Genocide and other instances of mass murder have shown that extermination policies usually constitute complex processes of radicalization that depend on a range of situational factors such as military defeats, panic, or shortage of food during war. Empirical studies have further revealed that most cases of mass violence have not been exclusively organized by central authorities or carefully planned long before the actual crime. Moreover, a clear cut distinction between perpetrators and victims, as suggested by the legal definition, cannot be observed in all cases of genocidal violence. The agency of persecuted groups should not be completely ignored. Threatened minority groups often manage to defend themselves more or less successfully and thus provoke even more violent reactions from their persecutors. Of course, this does not mean that victims are to be blamed for their fate. Nevertheless, genocidal violence is not always a onesided process determined by unequivocal role allocation. The examples of Rwanda and Darfur are illustrative: Many of the perpetrators of the Rwandan Genocide 1994 were themselves victims of mass violence or expulsion. In Burundi, the Tutsidominated army had committed large-scale massacres against the Hutu in 1972 and 1988. Pogroms and the assassination of Melchior Ndadaye, Burundi's first Hutu president, led another wave of refugees to Rwanda in 1993. Many of these unwelcome, deprived, and radicalized refugees supported the exterminationist anti-Tutsi policy of the Rwandan Hutu extremists in order to take revenge and benefit from the dispossession of the victims. While the international community failed to prevent mass violence in Central Africa, Paul Kagame and his Rwandan Patriotic Front (RPF) defeated the Hutu extremists and halted the genocide. Western media and politicians have celebrated Kagame as a savior and perceived the new Rwandan regime as a reliable ally in an unstable region. The international appreciation of Kagame ignores the fact that the RPF committed grave war crimes in 1994 and launched a war of plunder and exploitation in Eastern Congo. The example of Rwanda shows that victims can become perpetrators and vice versa. The same can be said for Darfur: Civil war and state failure in Western Sudan have fostered the development of warlordism and markets of violence. The social anthropologist Georg Elwert has defined a "market of violence" as "a field of activity which is mainly characterized by economic aims, in which both robbery and barter and the related activities of collection of ransoms, protection money, road tolls, etc. feature." 23 Warlords do not only pursue political aims but are, above all, entrepreneurs or managers of violence. International relief supplies are one of the most important and contested resources 
in a market of violence. The actors' original political or ideological motives take a backseat in long-standing civil wars and interfere with economic interests. Changing alliances are not unusual. As a result, the belligerents are not interested in a stop to hostilities since the war offers them considerable freedom of action. The situation in Darfur is thus much more complicated than the way in which it is generally portrayed in Western media. It is difficult to get an accurate overview of all the paramilitary organizations and their splinter groups fighting one another. But what is certain is that the general population is victimized by both "Arab" and "African" militias benefitting from the crisis in one way or another and committing crimes against humanity.

The example of Darfur clearly shows that the perpetrators of mass violence do not rely on a single motive. Therefore, the distinction between ideological and utilitarian genocides, which can be found in much of the literature on genocide, does not make too much sense. ${ }^{24}$ Such typologies of genocide are rather artificial and useless for historical research as most génocidaires pursue both ideological and economic interests. Expropriation, expulsion, and mass murder are thus often intertwined and part of the same process of annihilation.

Equally problematic is the traditional assumption that genocide is in the first instance a state-sponsored crime ordered and implemented by governments. Such an understanding overestimates the strength of state structures and the power of extremist governments in times of war and crisis. Furthermore, a state-centered focus ignores the participation of diverse social groups and local actors in mass violence. This aspect is crucial to an understanding of the dynamics of genocidal violence, as the following examples show: Broad sections of German society benefited from the dispossession of the Jewish population and, therefore, supported the antiSemitic policy of the Nazi government. When Omar al-Bashir claims he has no control over the infamous Janjaweed militias in Darfur he tries to minimize his own responsibility. Nevertheless, it cannot be denied that Sudan is a weak state and the government enjoys only limited influence at the periphery. Local warlords and militia leaders successfully fill the vacuum of power and pursue independent strategies. Finally, the expulsion and annihilation of the Ottoman Armenians during World War I could not have been carried out as smoothly as it was without the assistance of autonomous Kurdish tribes.

In a nutshell, there are many methodological problems and inadequacies inherent in the concept of genocide as it is used in the social sciences. For this reason, some scholars reject its application outside the realm of international law. ${ }^{25}$ But are there any reliable alternatives? Mark Levene has brought forward the concept of "zones of violence." This approach implies a geographical focus and aims to examine the violent exchange between several population groups in so-called borderlands in the longue durée. This framework's innovative potential lies in its transnational orientation. The dynamics of mass violence can only be adequately understood if broader regional contexts are taken into account. Refugee flows, famines, epidemics, and environmental degradation are phenomena that cross national borders and often contribute to political tensions and outbreaks of mass violence. ${ }^{26}$ Christian Gerlach has recently suggested another alternative to the concept of genocide: "extremely violent societies." Gerlach aims to overcome the methodological problems inherent in the concept of genocide, namely intentionalism, mono causality, and above all state-centrism. Gerlach is therefore in favor of a much more dynamic and flexible model: 
By extremely violent societies, I mean formations where various population groups become victims of massive physical violence, in which acting together with organs of the state, diverse social groups participate for a multitude of reasons. Simply put, the occurrence and the thrust of mass violence depends on broad and diverse support, but this is based on a variety of motives and interests that cause violence to spread in different directions and in varying intensities and forms. ${ }^{27}$

But when does a society become "extremely violent"? Gerlach argues that modern mass violence often occurs during periods of socioeconomic transition and in the context of violent transformation of non-industrialized regions. According to Gerlach, extremely violent societies witness struggles between elites and the emergence of a new economic and political leadership. Redistributive processes such as revolution, war, famine, or inflation are radicalizing factors. ${ }^{28}$ Gerlach asserts that his concept is more descriptive than analytical. Insofar as his approach is problematic, it is rather broad and encompasses too many disparate cases. And is it appropriate to blur the distinction between different forms of mass violence? A great majority of scholars do not see the necessity to abandon the genocide concept and reject Gerlach's alternative suggestion because it underestimates the role of the state and the significance of ideologies and racism. ${ }^{29}$ Even if the last word has not been spoken yet, Gerlach's proposal has caused a much-needed methodological debate in genocide studies.

\section{Genocide Studies and Memory Politics}

Gerlach's insistence on the fact that genocidal violence is usually targeted at various population groups is one of the key virtues of his model. The extermination policy of the Nazis is almost exclusively associated with Jewish victims in public memory. The victimhood of other groups such as Sinti and Roma, Poles, mentally disabled persons, and homosexuals is generally neglected. ${ }^{30}$ It is true that the Young Turks were especially obsessed with the destruction of the Armenians. However, the dissolution of the Ottoman Empire affected other minorities such as Greeks, Assyrians, and certain Kurdish groups as well. ${ }^{31}$

Why are some victim groups forgotten and others not? Or, more generally, why are some cases of genocide remembered and others buried in oblivion? The answer is related to a disturbing phenomenon: Different victim groups compete with each other in an arena of memory politics. ${ }^{32}$ The degree of recognition of a victim group's fate depends to some extent on the power of respective lobbies and their ability to mobilize public opinion and raise international pressure. Genocide is the worst possible crime. Therefore, victims of mass violence want their fate to be recognized as genocide. They see international recognition as a form of symbolic reparation. The most important arenas of memory politics are international bodies, national parliaments, national and international courts of justice, and, most notably, historiography. Lobbies of different victim groups compete on these fields in order to gain media and scholarly attention. Armenian activists have been very successful in this respect. Although the Turkish government still practices a cynical policy of denial, the murder of the Ottoman Armenians is no longer a forgotten genocide. Its public denial is more and more constrained. In Switzerland and France, for example, the negation of the Armenian Genocide is prohibited. But whereas the Swiss "antiracism law" of 1994 prohibits the general denial of genocide, French legislation considers only the denial of the Holocaust or the Armenian case as punishable offenses. This is a highly problematic approach because it attaches great importance to these 
two cases of genocide and plays down other instances of mass violence. Either unconsciously or consciously, genocide scholars often contribute to hierarchies of suffering by using biased terms such as "the first genocide of the twentieth century" and categories like "modern genocide," "pre-modern genocide," "ideological genocide," or "utilitarian genocide." Of course, this does not mean that it is impossible to make distinctions. Indeed, there is a wide range of forms and methods of mass violence. However, categorizations should be guided by scholarly principles and contribute to analytical insights, not to politics of memory.

\section{Concluding Remarks: Is There a Future for Genocide Studies?}

Genocide scholars from all around the world have contributed to a deeper understanding of mass violence in the past decades. So far, the development of genocide studies has proved to be a success story. However, severe methodological and ideological implications hamper the further development of the field. Historians and international lawyers prefer different approaches that are in many ways difficult to reconcile. There is no consensus on how to define genocide. Moreover, genocide research is a victim of its own success. Activists and profit-oriented actors have entered the stage and dominate the external perception of the field. To be sure, the struggle for human rights and the prevention of mass violence are important and respectable tasks. But activists and scholars pursue different strategies. Whereas scholars are bound to scientific standards and objectivity, activists want to mobilize public opinion through the spread of simple truths.

As a result of these developments it is legitimate to ask if there is a future for genocide studies. The answer is definitely yes. The field of genocide studies has much potential: Interdisciplinarity, though sometimes difficult, is the primary advantage genocide research offers. A complex phenomenon like mass violence cannot be studied by historians alone. The methods and insights of social psychology, sociology, and many other disciplines are indispensable. But we need more Lemkin and less Clooney. In other words, the influence of activism in the realm of genocide scholarship must be clarified.

\section{Notes}

1. Raphael Lemkin, Axis Rule in Occupied Europe: Laws of Occupation, Analysis of Government, Proposals for Redress (Washington, DC: Carnegie Endowment for International Peace, 1944), 79.

2. A. Dirk Moses, "Raphael Lemkin, Culture, and the Concept of Genocide," in Oxford Handbook of Genocide Studies, ed. Donald Bloxham and A. Dirk Moses (Oxford: Oxford University Press, 2010), 19-41, 34.

3. However, Lemkin was a tragic figure. During his lifetime he never got the recognition he deserved. He was nominated numerous times for the Nobel Peace Prize, but never actually received the honor. Neither his autobiography nor his works on the history and sociology of genocide were published. He died as an impoverished and isolated man in 1959.

4. Anton Weiss-Wendt, "Hostage of Politics: Raphael Lemkin on Soviet Genocide," Journal of Genocide Research 7, no. 4 (2005): 551-59.

5. See the contributions collected in Dominik J. Schaller and Jürgen Zimmerer, eds., The Origins of Genocide: Raphael Lemkin as a Historian of Mass Violence (London: Routledge, 2009).

6. The general admiration for Lemkin is sometimes both too enthusiastic and uncritical. On Lemkin's racist perception of Africans, see Dominik J. Schaller, "Raphael Lemkin's View of European Colonial Rule in Africa: Between Condemnation and Admiration," Journal of Genocide Research 7, no. 4 (2005): 531-38. 
7. Jean-Baptiste Michel et al., "Quantitative Analysis of Culture Using Millions of Digitized Books," Science 331, no. 6014 (2011): 176-82.

8. Google Ngram Viewer, http://ngrams.googlelabs.com/graph?content=genocide\%2Cmassacre\& year_start=1944\&year_end=2004\&corpus=0\&smoothing=3 (accessed 10 February 2011).

9. David Lanz, "Save Darfur: A Movement and its Discontents," African Affairs 108, no. 433 (2009): 669-77.

10. Stephanie Strom and Lydia Polgreen, "Darfur Advocacy Group Undergoes a Shake-Up," New York Times, 2 June 2007.

11. Norman G. Finkelstein, The Holocaust Industry: Reflection on the Exploitation of Jewish Suffering (London: Verso, 2000).

12. Dominik J. Schaller, "Genocide Tourism-Educational Value or Voyeurism?," Journal of Genocide Research 9, no. 4 (2007): 513-15.

13. A. Dirk Moses, "Toward a Theory of Critical Genocide Studies," Online Encyclopedia of Mass Violence, 18 April 2008, http://www.massviolence.org/Toward-a-Theory-of-CriticalGenocide-Studies (10 February 2011).

14. Mark Levene, Genocide in the Age of the Nation State, vol. 1, The Meaning of Genocide (London: I.B. Tauris, 2005), 173.

15. This narrative is prevalent in Samantha Power's award-winning work. Samantha Power, "A Problem from Hell": America and the Age of Genocide (New York: Basic Books, 2002).

16. William D. Rubinstein, Genocide: A History (London: Longman, 2004), 102-103. The work of Niall Ferguson rests upon the same line of argument. See Niall Ferguson, Empire: The Rise and Demise of the British World Order and the Lessons for Global Power (New York: Basic Books, 2003).

17. The most important contributions are Mark Levene, Genocide in the Age of the Nation State, vol. 2, The Rise of the West and the Coming of Genocide (London: I.B. Tauris, 2005); Michael Mann, The Dark Side of Democracy: Explaining Ethnic Cleansing (Cambridge: Cambridge University Press, 2005); A. Dirk Moses, ed., Empire, Colony, Genocide: Conquest, Occupation, and Subaltern Resistance in World History (New York: Berghahn, 2008); Lorenzo Veracini, Settler Colonialism: A Theoretical Overview (Basingstoke: Palgrave Macmillan, 2010).

18. For an overview of colonial genocides in Africa, see Dominik J. Schaller, "Genocide and Mass Violence in the 'Heart of Darkness': Africa in the Colonial Period," in Bloxham and Moses, Oxford Handbook of Genocide Studies, 345-64.

19. For a review of the literature on the German genocide in Namibia, see Dominik J. Schaller, "Genocide in Colonial South-West Africa: The German War Against the Herero and Nama, 1904-1907," in Genocide: A Critical Bibliographic Review, vol. 8, Genocide of Indigenous Peoples, ed. Samuel Totten and Robert K. Hitchcock (New Brunswick: Transaction, 2011), $37-60$.

20. For an overview of the range of Lemkin's historical writings and a discussion of his methods, see John Docker, “Are Settler-Colonies Inherently Genocidal? Re-Reading Lemkin,” in Moses, Empire, Colony, Genocide, 81-101.

21. Lemkin, Axis Rule, 82-90.

22. According to the UN Convention on the Prevention and Punishment of the Crime of Genocide, genocide means any of the following acts committed with intent to destroy, in whole or in part, a national, ethnical, racial or religious group, as such:

(a) Killing members of the group;

(b) Causing serious bodily or mental harm to members of the group;

(c) Deliberately inflicting on the group conditions of life calculated to bring about its physical destruction in whole or in part;

(d) Imposing measures intended to prevent births within the group;

(e) Forcibly transferring children of the group to another group.

See Convention on the Prevention and Punishment of the Crime of Genocide, 9 December 1948, 78 U.N.T.S. 277, Article II, http://www.preventgenocide.org/law/convention/text.htm (accessed 17 October 2011). 
23. Georg Elwert, "Markets of Violence," in Dynamics of Violence: Processes of Escalation and De-Escalation in Violent Group Conflicts, ed. Georg Elwert, Stephan Feuchtwang, and Dieter Neubert (Berlin: Duncker und Humblot, 1999), 87.

24. For an influential typology of genocides, see Frank Chalk and Kurt Jonassohn, The History and Sociology of Genocide: Analyses and Case Studies (New Haven: Yale University Press, 1990), 29-32.

25. Christian Gerlach, "Nationsbildung im Krieg: Wirtschaftliche Faktoren bei der Vernichtung der Armenier und beim Mord an den ungarischen Juden" [Nationbuilding and war: Economic motives in the destruction of the Armenians and the murder of the Hungarian Jews], in The Armenian Genocide and the Shoah, ed. Hans-Lukas Kieser and Dominik J. Schaller (Zürich: Chronos, 2002), 350.

26. Mark Levene, "Creating a Modern 'Zone of Genocide': The Impact of Nation- and StateFormation on Eastern Anatolia, 1878-1923," Holocaust and Genocide Studies 12, no. 3 (1998): 393-433.

27. Christian Gerlach, Extremely Violent Societies: Mass Violence in the Twentieth-Century World (Cambridge: Cambridge University Press, 2010), 1-2.

28. Ibid., 266-89.

29. Alex Hinton, "Genocide and Mass Violence: A Conceptual Turn?," Journal of Genocide Research 9, no. 1 (2007): 11-14.

30. One key exception is Century of Genocide: Critical Essays and Eyewitness Testimony, ed. Samuel Totten and William S. Parsons (New York: Garland, 1995, 1997; New York: Routledge, 2004, 2009). The first (1995) through the third editions (2009) all include individual chapters on the Nazi extermination of the Jews, the Sinti-Roma, and the mentally and physically handicapped.

31. For the complexity of the Young Turks' policy of extermination, see Uğur Ümit Üngör, The Making of Modern Turkey: Nation and State in Eastern Anatolia, 1913-1950 (Oxford: Oxford University Press, 2011); Dominik J. Schaller and Jürgen Zimmerer, eds., Late Ottoman Genocides: The Dissolution of the Ottoman Empire and Young Turkish Population and Extermination Policies (London: Routledge, 2009); David Gaunt, Massacres, Resistance, Protectors: Muslim-Christian Relations in Eastern Anatolia during World War I (Piscataway, NJ: Gorgias Press, 2006).

32. Jean-Michel Chaumont, La concurrence des victims: Génocide, identité, reconnaissance [The competition of victims: Genocide, identity, recognition] (Paris: Editions La Découverte \& Syros, 1997). 